Meta

Journal des traducteurs

Translators' Journal

\title{
Sociolinguistic Obstacles to Communication through Translation
}

\section{Charles R. Taber}

Volume 25, numéro 4, décembre 1980

URI : https://id.erudit.org/iderudit/004315ar

DOI : https://doi.org/10.7202/004315ar

Aller au sommaire du numéro

Éditeur(s)

Les Presses de l'Université de Montréal

ISSN

0026-0452 (imprimé)

1492-1421 (numérique)

Découvrir la revue

Citer cet article

Taber, C. R. (1980). Sociolinguistic Obstacles to Communication through

Translation. Meta, 25(4), 421-429. https://doi.org/10.7202/004315ar d'utilisation que vous pouvez consulter en ligne.

https://apropos.erudit.org/fr/usagers/politique-dutilisation/ 


\title{
Sociolinguistic Obstacles to Communication through Translation
}

\author{
CHARLes R. TABER
}

The topic of this paper is a cluster of matters which constitute obstacles to effective communication through translation. I want to suggest that these obstacles are sociolinguistic questions; i.e., that they stem from socially induced ideas about language, about speakers of languages, about communication, about texts, and about translation. The attitudes and notions $I$ will describe are thus not idiosyncratic to individual translators; nor do they rest on what might be called "objective" properties of language and its uses. They are nevertheless very real obstacles which interfere severely with the communicative efficacy of translations.

My data base is taken chiefly from the field of Bible translation, and is anecdotal. While this may well vitiate the rigor of the analysis, it in no way militates against its representativeness, since Bible translation is the most widely practiced type of translation and involved persons from all parts of the world, all levels of education and sophistication, and all possible permutations of cultural and linguistic diversity.

I recognize the frequency of three kinds of problems that I will not be discussing, except insofar as they are caused by the factors I am concerned with. Translators often have an inadequate knowledge of the source language, even when they are native speakers of it; they often have inadequate knowledge of the receptor language, even when they are native speakers of it; and they often lack an adequate grasp of translation principles and procedures. These are no doubt statistically the most frequent causes of communicative failure in translation. But as long as they represent merely individual deficiencies of translators, they do not concern me. I will focus instead on some sociocultural sources of these and other problems; that is, concrete social, political, economic, and cultural relations between persons, especially as these are systemic and structural in nature, and the resulting ideational or ideological structures which justify or undermine the structures and institutions involved. However, since these factors come to focus in the heads and behaviors of specific translators and receptors, I will spend most of my time in these locuses. And of course, because of the complexity of the material I have space to do little more than offer a classification of problems. Full exemplification and explanation would require a book. 


\section{PROBLEMS IN THE CIRCUMSTANCES}

Since I am dealing with sociogenic and culturogenic questions I begin by discussing three factors which exist in the general circumstances in which translators translate and receptors respond to translations: dominance relations between translators and receptors, illiteracy among receptors, and sociocultural distance between translators and receptors.

1. Dominance relations between translators and receptors. Ideally, the most effective communication takes place when translator and receptors are peers bound together by a relationship of trust. Any inequality, especially as it becomes marked, constitutes a severe problem for communication because it undermines understanding and trust. The worst effects exist in situations of slavery or of colonization; but in an emotionally charged or polarized situation tense employer-employee relationships also defeat communication. The present situation in which the industrialized nations manipulate and exploit the poor nations throws up almost insurmountable barriers to communication between citizens of the respective blocs.

The effects of unequal relations are twofold. On the one hand, they almost always lead to profound ignorance of the dominated people by the dominators. Colonizers rarely understand the colonized, slave owners rarely understand slaves, and so forth. This is partly because the dominated people are considered unworthy of serious notice, so that their needs, their hopes, their aspirations can justifiably be ignored; and also because to recognize their worth and dignity would undermine the relation of dominance, which must be maintained. The dominated, of course, usually understand the dominators very well, since it is for them a matter of survival.

On the other hand, relations of dominance almost always cause a reaction of rejection by the dominated of ideas pushed on them by the dominators. They insist on defining an area, even if it is only in their minds, which remains independent of the dominators and in which they can protect the residue of their sense of identity and integrity.

2. Massive illiteracy among receptors becomes a problem when translators operate on the assumption that translations are meant to be read privately and individually. This can theoretically be remedied by programs of literacy education; but where for reasons of scale or resistance mass literacy is not a possibility, the printed page ipso facto fails to communicate through the ear, since the constraints of the two channels are quite different. Some persons are experimenting with translations intended for use via radio or cassettes. As far as the biblical texts are concerned, this is of course to return to the way they were originally used.

3. Sociocultural distance. Even in situations where no dominance is involved, a translator may fail to make sufficient allowance for the effects of sociocultural distance on the way people will understand his translation. Each of us interprets any utterance or text on the basis of implicit information 
supplied by our worldview, our current state of knowledge, our beliefs, our values, our attitudes. A particularly forceful and amusing instance is provided by the anthropologist Laura Bohannan ${ }^{1}$. She recounts her attempt among the Tiv of Nigeria, when it became her turn to tell a story around the fire, to explain Hamlet. It turned out that every one of the psychosocial keys to the motivation of the play were unintelligible and unacceptable to the Tiv. I also cite the way in which a Thai Buddhist might well understand John 3:16 in the common Thai Bible on the basis of one mistranslated word and the postulates of Buddhism: "For God so lusted after the material universe that he gave his only Son (?), so that whoever is gullible enough to believe him can never escape, but is condemned to continue to exist forever."

The situation can be greatly aggravated when the translator is a part of neither the world of the source nor of that of the receptors, which is by definition the case for missionary translators of the Bible.

\section{PROBLEMS IN THE TRANSLATOR'S HEAD}

On the basis of his or her own place in the structural and systematic relationships the context creates, and of attitudes and values inculcated into him or her in the process of socialization (including professional training), the translator develops certain notions and attitudes which affect the translation in various ways.

1. Attitudes towards receptor persons. Though it is probably initial perceptions of cultural differences that generate prejudice, once the pattern is set it is at its most virulent in its expression against persons. The dark side of pride in one's family, community, class, nation, or race is the hatred, contempt, fear, and so on that it engenders towards persons who are different. In the situations in which translation is often done, especially in the Third World, historic and contemporary relations of conquest, colonization, and economic exploitation give rise in the dominant group to feelings of contemps towards the dominated. Since the latter are often also illiterate and poor, translators, even those who labor out of a deep devotion to their cause, can and do sometimes feel and express contempt for the receptors. But even though the feelings are at their most blatant in the Third World, they exist in the relationships between westerners and members of advanced and sophisticated non-western societies, e.g. the Muslim World, or China in the 19th century. It exists also in the attitudes of some of these non-westerners towards the West, as you well know.

The belief that receptors are inferior manifests itself in various ways in translation.

There is first the widespread pattern according to which the westerner in a non-western situation is called "the translator" while local participants in the project are "informants" or "translation helpers". This subordination of the

1. Laura Bohannan, "Shakespeare in the Bush", Natural History (August-September, 1966). 
native speakers could not but vitiate their contribution, and consequently produce a less than ideal translation. The "translator" places far too much confidence in his own expertise, even though his knowledge of the receptor language is deficient. Bible translations done under these conditions range from the barely adequate to the abysmally bad. But translators in this frame of mind are insulated against awareness of the flaws of their work; as one said, when it was pointed out that his version was quite unintelligible, "We're not making this translation for stupid people." Since this was his judgment of almost all Africans, it is not clear for whom he was translating!

A peculiarly noxious effect of this attitude is that it leads one to discount, to distort, or to fail to hear the feedback of receptors by which they try to let the translator know how they interpret his efforts. Confident in his mastery and contemptuous of their supposed inability, the translator forges ahead regardless of all warning signals.

Contempt for receptors' competence leads to transgressing the fine line between making explicit just enough of the implicit information from the original, and making too much explicit ${ }^{2}$. Because receptors are judged incapable of exercising intelligent ingenuity and empathy, translations are sometimes made which are bloated compendia of all that the translator could not bear to leave to their imagination. Such efforts in English as The Amplified Bible ${ }^{3}$ result in part from an unavowed contempt for the sense and sensitivity of readers. Other factors, of course, are also involved.

Finally, contempt for receptors leads sometimes to excessive and misguided cultural adaptation. In one translation in West Africa, where grapewines are of course locally unknown, translators substituted "coffee tree" for grapevine in John 15. But when bilingual receptors compared their Bible with the French version, they were deeply offended by the condescension which the substitution represented. I am sure that J. B. Phillips ${ }^{4}$ was not motivated by contempt but by a genuine desire to communicate when he substituted "a hearty handshake" for "a holy kiss" (1 Cor. 16.20; 2 Cor. 13.12) and "ill from some psychological cause" for "had an evil spirit" (Luke 13.11); but some readers will no doubt consider this an insult to their intelligence. As with the matter of explicit and implicit information, this is an area where enormous sensitivity is called for - a sensitivity unlikely to coexist with contempt for receptors.

2. Attitudes towards the receptor language. Contempt for the receptor language is strongest when it is initially an unwritten language. The popular phrase "to give the people a language" reflects this attitude. It is assumed by many, including not a few translators, that when a language is unwritten it is ipso facto deficient and disordered; just as it does not have an orthography,

2. Charles R. Taber, "Explicit and Implicit Information in Translation", The Bible Translator, XXI, 1 (1970), p. 1-9.

3. The Amplified Bible, Grand Rapids, Zondervan, 1965.

4. J. B. Phillips, The New Testament in Modern English, London, Geoffrey Bles Ltd., 1960. 
it does not have a grammar, and it becomes the task of the translator to create one. Manifestations of this attitude fall into three classes.

First, some translators actually feel free to invent ad hoc and arbitrary rules. One translation committee I knew used to deliberate - in English about what rules to follow. These included not only spelling rules, but rules of morphology (which was unfortunate, since the language in question had virtually no indigenous morphological rules) and of syntax. From time to time "informants" were consulted on narrow and specific points, chiefly to resolve impasses among the expatriate translators. Strange and wonderful things occur when foreigners give themselves permission to invent rules for a language deemed not to have any. Of course, this is only a specific and especially virulent example of the general attitude according to which dictionaries and grammars are supposed to be prescriptive rather than descriptive, and which gives some English teachers permission to impose on students the inventions of various pedants of the past.

Second - and this is an extension of the first point - is the tendency of translators infected with this attitude to fill in what they perceive as systemic gaps in the structure of the receptor language. Just as grammars of "exotic" languages from a certain period abounded with statements like "this language does not have a passive, an aorist, etc.," so translators often feel called upon to remedy such defects by creating the missing forms. Thus many an unsuspecting African language has been endowed with a totally superfluous passive or what have you.

Finally, just as contempt for a language may lead one to "improve" it, it also leads one to overlook the rich resources it does offer, lexical or grammatical or stylistic, to express almost anything human beings might want to express. The popular mythology, abetted by some translators, is replete with tales of languages which lacked words for fundamental human experiences; in most cases, such statements reflect the inability of the translator to take the people and their language seriously enough to find out what resources they had. Hundreds of translations have been produced which fail to exploit entire lexical domains, whole sets of syntactic constructions, and whole complexes of stylistic and rhetorical devices. It is inevitable that such translations should appear at best anemic and flavorless, and at worst totally unintelligible.

3. Attitudes towards the source language andlor texts and towards "faithful translation". After initially separating this point into two parts, I have now lumped them, since in the absence of any explicit statement of rationale from the translator the practical effects of these factors are indistinguishable.

At this point I can broaden my data base, since this problem affects not only Bible translation but also literary translation. By it I mean any mental servitude to the surface form of the original text or any ideological commitment to a certain notion of "faithful translation". In other words, the attention of the translator, intent on representing faithfully what he conceives of as the significance of the source text and its forms, is led into slavish imitation and hence into awkward and unnatural expression in the receptor language. 
Few professional translators are as naive as a lady in Pennsylvania - totally monolingual - who asked me to provide her with an English-Sango dictionary so that she could translate at home Christian literature for the churches of the Central African Republic. But inadequate and even bizarre views about what constitutes fidelity in translation are rampant among people who do such work, if one can judge by the results. On the one hand are those notions that rest upon an obsession with lexicon; here I cite The Concordant Literal New Testament ${ }^{5}$, in which the guiding principle was to translate each Greek word by the same English word in all occurrences, regardless of contextual conditioning. Unfortunately I am obliged to leave the results of this effort to your imagination, since I have not been able to find a copy. Another focus is on the surface features of the syntax and style of the original, so that, e.g., the interminable sentence in the first chapter of Ephesians (vs. 3-14) remains one sentence in many English versions; or every Greek passive is mechanically represented by an English passive, even though passives are used in quite different ways in the two languages. I quote two passages which I judge to be translationally inadequate for such reasons :

(a) As far as here on earth is reckoned for a mile, so far had we now gone on from there, in short time because of ready will. And toward us were heard flying, not however seen, spirits uttering courteous invitations to the table of love ${ }^{6}$.

(b) For verily that which hath been made glorious hath not been made glorious in this respect, by reason of the glory that surpasseth (2 Cor. $3.10)^{7}$.

It is not clear whether such awful results stem from a systematic and principled approach, or merely from a vague but compelling fear of straying into "les belles infidèles" or, even worse, into "paraphrase". Similar results obtain when translators are moved by other types of mental predispositions, as when an Indian lay preacher translating the New Testament into his native Ojibwa (Pikangikum) refused to use the normal terms for pregnancy and childbirth in referring to the Nativity because "that was something special".

My reason for bringing the whole question up in this context is that many of these ideas represent ideological commitments, that is commitments which stem from the professional or doctrinal socialization of the translator - such a commitment, for instance, as that of many conservative Protestants to the theory of "plenary verbal inspiration" of the Scriptures, with its obvious focus on surface structure, which leads to an almost Muslim understanding of the connection between the form of the text and its authoritativeness (Orthodox Muslims are of course consistent enough to deny that the Qur'an can be translated authoritarively). Similar ideological positions seem to me to underlie some of the more unfortunate efforts in the field of literary translation, though I am less familiar with the evidence. The general effect of such notions is to remain slavishly tied to the surface structure of the original and to fail to exploit the rich

5. The Concordant Literal New. Testament, Canyon City, Concordant Publishing Concern, 1926.

6. Dante Alighiere, Divine Comedy, "Purgatory," xiii. $22 \mathrm{ff}$, tr. by Charles Eliot North, Chicago, Encyclopaedia Britannica, 1952.

7. The American Standard Version, New York, Thomas Nelson and Sons, 1901 
and complex nature of the connections between deep and surface structures in both languages involved.

\section{PROBLEMS IN THE RECEPTORS' HEADS}

Translators are not the only persons who contribute to communicative failure. The receptors also may have ideas that create obstacles to effective communication.

1. Attitudes towards the translator. Whether or not there is a systemic dominance relationship between translator and receptor, the receptor will often find the translator's motives incomprehensible and hence suspect and his behavior bizarre and offensive, especially when the translator is a foreigner. If in addition the translator is a member of a dominant group, the receptors may simply ignore his efforts.

2. Attitudes toward their own language. Surprisingly, there is not infrequently a belief that the receptor language, or at least that form of it with which people are most at home, is inferior or inappropriate for written communication. In some African cases, people are known to reject translations in their tribal language in favor of translations in a trade language, even though they may not be fully competent in the trade language. Many of these people are illiterate or semi-literate, so that the mystique of print carries enormous weight; people often have the idée fixe that material important enough to be written must be written in a language more prestigious than the familiar one they use at home. Similar is the rejection, in much of the Arabic-speaking world, of translations in regional or local dialects. The official doctrine is that serious matters, especially in writing, require the use of classical Arabic, which "has not changed since the days of the Prophet Muhammad". Even scholars in the field of language are often impervious to contrary empirical evidence; and with the general public it is unquestioned dogma. In the West, efforts to provide biblical translations in non-standard and unprestigious speech forms, e.g. youth slang or Black English, have met with great resistance, not least from those who used these speech forms. The Cotton Patch Version, done by Clarence Jordan, is an exemple ${ }^{8}$.

Finally, the extraordinary role of the King James Version (or Authorized Version) in English and the correlative resistance of many to versions that are not only more accurate but more intelligible rests chiefly on the mystique of its "sacred" language, which turns out to consist of a combination or archaism and translational literalism. Not a few people say of modern versions: "This can't be the Bible; I can understand it."

3. Attitudes about the use of texts. Chiefly, these attitudes militate against a moral use of texts as material to be read consecutively. In the case of the Bible, the artificial and arbitrary division of the text into chapters and verses which are often printed as separate paragraphs, lends itself to a widespread use of the

8. Clarence Jordan, The Cotton Patch Version of the New Testament (4 vols.), New York, Association Press, 1968-1973. 
Bible as a compendium of isolated sentences, which can with ingenuity be used to justify any previously chosen argument. In other cases, the Bible - either the text or the physical book - can be used magically as in healing, in casting or warding off spells, and the like.

\section{CONCLUSIONS}

Any situation which is as complex in its dimensions as the attempt to communicate through translation will of necessity call upon a number of disciplines to provide conceptual and methodological clarification. Among these, at least, will be linguistics, anthropology, communication theory, sociology of knowledge, and sociolinguistics. Yet it is to be hoped that the resulting model will be more than a scissors-and-paste juxtaposition of disparate notions. In the attached diagram, I attempt to pull these factors together into a coherent whole; note that I do not make explicit the disciplinary source of each element, though this could of course be done.

The diagram specifies three horizons : that of the original, that of the translator, and that of the receptors. Three patterns are plausible with respect to similarity or difference between these: (a) $\mathrm{T}$ and $\mathrm{R}$ are similar, while $\mathrm{O}$ is different; (b) $\mathrm{T}$ and $\mathrm{O}$ are similar, while $\mathrm{R}$ is different; (c) all three are different. No other combination is plausible ${ }^{9}$.

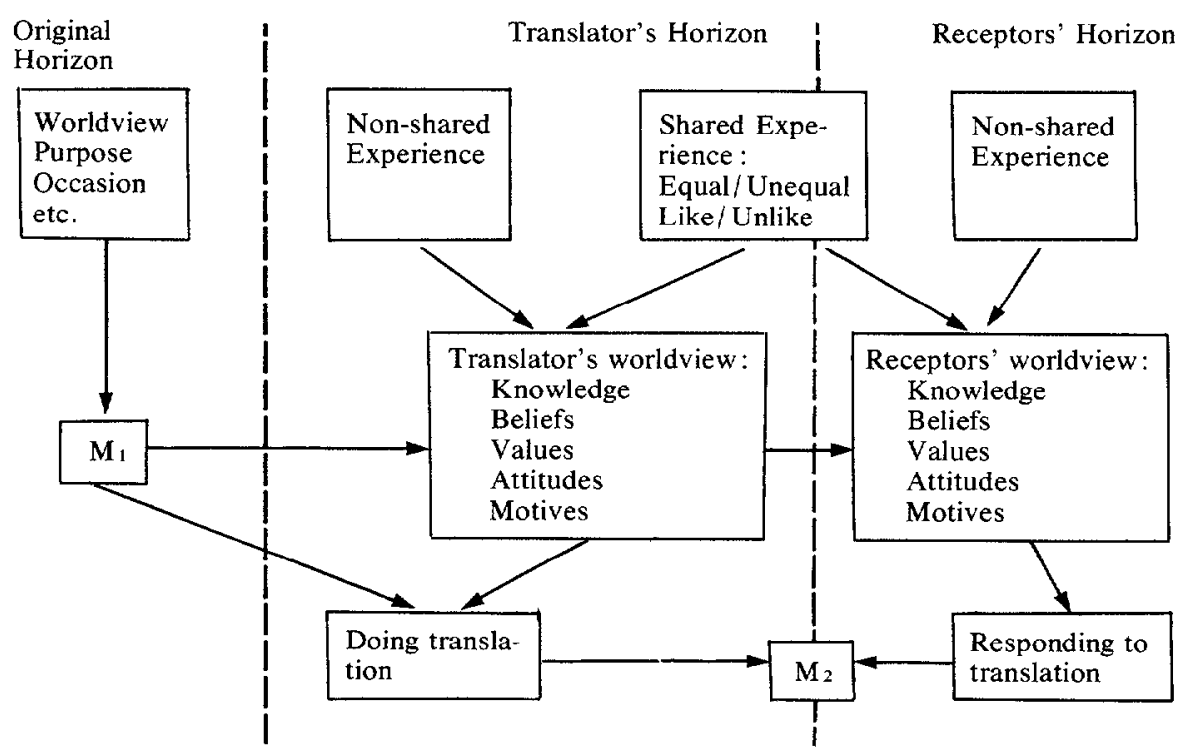

It will be noted that since $\mathrm{T}$ and $\mathrm{R}$ are necessarily in some kind of relationship, often one which is not just individual but structural and systemic, the nature of their concrete relationship - equal or unequal, close or distant -

9. In discussion at the consultation, it was pointed out to me that with certain kinds of technical material, $O$ and $R$ may share a disciplinary horizon which a professional $T$ does not fully share. The $T$ bridges the linguistic gap between 0 and $R$. 
feeds into the worldview of each; this is the crucial insight of the sociology of knowledge. That is, as soon as persons come into contact, whether of like or unlike culture, their respective worldviews are from that point affected not only by each other's ideas but by how they treat each other, by who has the upper hand, how it was gained, and how it is exercised. Note that the equal/unequal factor is independent of the like/unlike factor, so that even when persons share a basically similar culture, their concrete relationships in terms of class, sex, age, or any other sociological variable will affect how they understand one another and how they communicate with one another, in translation as in any other way. This also takes into consideration sociolinguistically conditioned differences of understanding of vocabulary and other linguistic forms and devices.

Note that while $T$ may appear to have direct access to $M_{1}$, on the whole his or her worldview - including that part of it that derives from contact with $R$ - impinges on how he or she interprets $M_{1}$. That is, one's worldview necessarily affects one's hermeneutics.

Note also the short arrow linking T's worldview with that of R; this represents T's effort, sincere or not, successful or not, to take R's worldview into account in translating.

This model makes explicit that no one operates in objective isolation alone with a text which is to be translated. Sociological and cultural factors of all sorts enter into the hermeneutics of the translator and into the translation process. It behooves us, then, to recognize them for what they are and to make allowances for them as best we can. Unfortunately, I can offer you no algorithm, no royal road to success, but only urge you to apply your awareness with humility and integrity to your task. 